\title{
Keefektifan Model Problem Based Learning terhadap Kemampuan Berpikir Kritis Tema Panas dan Perpindahannya
}

\author{
Salis Mahfudah ${ }^{1}$, Ary Susatyo ${ }^{2}$, Ari Widyaningrum ${ }^{3}$ \\ 1,2,3 Pendidikan Guru Sekolah Dasar, Fakultas IImu Pendidikan \\ Universitas PGRI Semarang, Indonesia \\ e-mail: salismahfudah96@gmail.com
}

\begin{abstract}
Abstrak
Tujuan yang hendak dicapai dalam penelitian ini adalah untuk mengetahui keefektifan model pembelajaran problem based learning terhadap kemampuan berpikir berpikir kritis siswa tema panas dan perpindahnnya SD Negeri Tlogomulyo Semarang tahun ajaran 2018/2019. Metode yang digunakan dalam penelitian ini adalah penelitian kuantitatif. Penelitian ini meruapakan penelitian pre-Experimental design dengan jenis One group pretest dan posttest design. Subyek penelitian adalah siswa kelas av sd negeri Tlogomulyo Semarang dengan jumlah 45 siswa. Berdasarkan hasil analisis menunjukkan bahwa pembelajaran menggunkan model problem based learning learning efektif terhadap kemampuan berpikir kritis tema panas dan perpindahannya siswa kelas V SD Negeri Tlogomulyo Semarang. Dilihat dari rata-rata pretest yang awalnya adalah 48 dan setelah melakukan postest rata-rata nilainya adalah 83. Pada saat pretest dari 45 siswa tidak ada yang tuntas, setelah melakukan posttest ada 39 siswa tuntas dan 6 siswa belum tuntas. Hal tersebut diperkuat dengan hasil analisis akhir yang telah dilakukan dengan menggunakan uji $t$ bahwa hasil $t_{\text {hitung }}>t_{\text {tabel }}$ yaitu 23,865 $>1,671$ diperoleh $\mathrm{t}_{\text {hitung }}=23,865$ dengan $\mathrm{db}=45-1=44$ pada taraf signifikan $\alpha=5 \%$ diperoleh indeks $\mathrm{t}_{\text {tabel }}=1,671$. Karena $\mathrm{t}_{\text {hitung }}>\mathrm{t}_{\text {tabel }}$ maka $\mathrm{H}_{\mathrm{o}}$ ditolak dan $\mathrm{H}_{\mathrm{a}}$ diterima, sehingga dapat disimpulkan bahwa kemampuan berpikir kritis setelah menggunakan model problem based learning lebih baik sebelum menggunakan model pembelajaran problem based learning.
\end{abstract}

Kata kunci : Model Problem Based Learning, Kemampuan Berpikir Kritis, Tema Panas dan Perpindahannya

\begin{abstract}
The aim to be achieved in this study is to determine the effectiveness of the problem based learning learning model on the ability to think critically in students of the theme of heat and the transfer of SD Negeri Tlogomulyo Semarang in the academic year 2018/2019. The method used in this study is quantitative research. This research is a pre-Experimental design study with one group pretest and posttest design. The research subjects were students of grade av to the state of Tlogomulyo Semarang with a total of 45 students. Based on the results of the analysis showed that learning using the problem based learning learning model is effective against the critical thinking skills of the theme of heat and displacement of fifth grade students of SD Negeri Tlogomulyo Semarang. Judging from the average pretest that was initially 48 and after doing the posttest the average value was 83. At the pretest of 45 students there was no completion, after doing the posttest there were 39 students completed and 6 students not yet finished. This is reinforced by the results of the final analysis that has been done using the test that the results of $\mathrm{t}_{\text {count }}>\mathrm{t}_{\text {table }}$ is 23.865> 1.671 obtained $\mathrm{t}_{\text {count }}=23.865$ with $d b=45-1=44$ at a significant level $\alpha=5 \%$ obtained index $t_{-}$table $=1.671$. Because $\mathrm{t}_{\text {count }}>\mathrm{t}_{\text {table }}$ then $\mathrm{H}_{\mathrm{o}}$ is rejected and $\mathrm{H}_{\mathrm{a}}$ is accepted, so it can be concluded that the ability to think critically after using the problem based learning model is better before using the problem based learning learning model.
\end{abstract}

Keywords: Model of Problem Based Learning, Critical Thinking Skills, Hot Themes and Their Movements 


\section{Pendahuluan}

Pendidikan pada hakikatnya adalah suatu proses kegiatan belajar mengajar yang ditandai adanya interaksi antara siswa dan guru. Kegiatan belajar mengajar ini dapat berlangsung secara efektif apabila seluruh komponen yang ada saling mendukung. Komponenkomponen dalam pembelajaram tersebut meliputi tujuan, materi, guru, metode, waktu yang tersedia, perlengkapan mengajar dan evaluasi pembelajaran. Menurut Lutvaidah (2015) Pendidikan merupakan sarana terpenuhinya proses belajar manusia. Tanpa pendidikan manusia tidak mampu mengembangkan fitrahnya sebagai insan pedagogik yang perlu dididik dan mendidik. Namun, suatu pendidikan akan mempunyai mutu yang tinggi apabila guru mempunyai mutu yang tinggi pula. Sedangkan mutu guru sangat ditentukan oleh pemahamannya tentang komponen, pendekatan, dan berbagai metode pengajaran yang diterapkan dalam proses pembelajaran. Usaha-usaha guru dalam mengatur dan menggunakan berbagai variabel pengajaran merupakan bagian penting dalam keberhasilan siswa mencapai tujuan yang direncanakan. Menurut Azmi (2016) Pendidikan merupakan usaha untuk membantu peserta didik mengembangkan seluruh potensinya (hati, pikir, rasa, dan karsa, serta raga) untuk menghadapi masa depan.

Dalam UU Nomor 20 tahun 2003 ; PP Nomor 19 tahun 2005 dikatakan bahwa "pembelajaran adalah proes interaksi peserta didik dengan pendidik dan sumber pada suatu lingkungan", sedangkan "kurikulum adalah seperangkat rencana dan pengaturan mengenai tujuan, isi, dan bahan pelajaran serta cara yang digunakan sebagai pedoman penyelenggaraan kegiatan pembelajaran untuk mencapai tujuan pendidikan tertentu". Kurikulum dan pembelajaran merupakan dua hal yang tidak bisa terpisahkan, meski berada pada posisi yang berbeda. Saat ini Kementerian Pendidikan dan Budaya telah menerapkan kurikulum 2013. Pengembangan kurikulum 2013 merupakan langkah lanjutan pengembangan kurikulum berbasis kompetensi yang telah dirintis tahun 2004 dan KTSP 2006 yang mencakup kompetensi sikap, pengetahuan, dan keterampilan secara terpadu. (UU RI No. 20, 2003)

Penerapan model pembelajaran 2013 bertujuan agar siswa dapat belajar secara mandiri sehingga proses pembelajaran yang berjalan sudah tidak lagi berpusat pada guru atau teacher centered.

Berdasarkan hasil observasi dan wawancara di kelas V SD negeri Tlogomulyo, pelaksanaan kurikulum 2013 dalam proses pembelajaran sudah menggunakan pendekatan scientific, akan tetapi belum optimal. Saat pembelajaran di kelas berlangsung cenderung terlihat penerapkan metode ceramah dan penugasan. Proses pembelajaran masih berpusat pada guru, sehingga keaktifan dan kemandirian belajar siswa masih kurang. Siswa cenderung kurang ulet dan teliti dalam menyelesaikan masalah, sehingga menyebabkan kemampuan berfikir siswa dalam menyelesaikan masalah yang diberikan masih rendah. Berdasarkan pemaparan guru, siswa juga masih kesulitan dalam berkomunikasi untuk menyampaikan pendapatnya, siswa kurang mengembangkan keterampilan dalam memecahkan masalah. Hal ini terjadi pada pembelajaran tematik pada tema Panas dan Perpindahannya.

Menurut Dewina (2017) dalam proses PBL, kegiatan yang dilakukan oleh guru adalah menghadirkan permasalahan dunia nyata di dalam kelas yang tentunya berkaitan dengan materi atau indikator yang akan dicapai, sehingga siswa akan terlibat langsung dalam memecahkan masalah yang ada. Menurut Fauziah (2018) model PBL merupakan model pembelajaran yang menyajikan masalah untuk diselesaikan siswa melalui diskusi kelompok sehingga siswa yang menjadi pusat pada proses pembelajaran bukan lagi guru. Model PBL membuat pembelajaran lebih bermakna dengan masalah yang disajikan, sehingga siswa dapat menemukan sendiri konsep matematika dari hasil diskusi yang mereka lakukan. Model Problem Based Learning (PBL) adalah model pembelajaran dengan pendekatan pembelajaran siswa pada masalah autentik sehingga siswa dapat menyusun pengetahuannya sendiri, menumbuh kembangkan keterampilan yang berlebih tinggi dan inquiry, memandirikan siswa dan meningkatkan kepercayaan diri sendiri (Hosnan, 2014: 295). Menurut Sianturi (2018) dalam model Problem Based Learning (PBL), fokus pembelajaran ada pada masalah yang dipilih sehingga siswa tidak saja mempelajari konsep-konsep yang berhubungan dengan masalah tetapi juga metode ilmiah untuk memecahkan masalah tersebut. Oleh sebab itu, siswa tidak saja harus memahami konsep yang relevan dengan masalah yang menjadi pusat perhatian tetapi juga memperoleh pengalaman belajar yang berhubungan dengan keterampilan menerapkan metode ilmiah dalam pemecahan masalah dan menumbuhkan pola berpikir kritis. Problem Based Learning mendorong siswa untuk menemukan pemecahan masalah yang diberikan dapat membantu untuk meningkatkan kemampuan diri siswa. Penerapan problem 
based learning merupakan suatu pendekatan pengajaran yang mempelajari masalah dunia nyata sebagai konteks bagi siswa untuk memperoleh pengetahuan serta konsep yang esensi dari mata pelajaran Berdasarkan uraian yang telah dijelaskan, maka peneliti mengadakan penelitian dengan judul " keefektifan model problem based learning terhadap kemampuan berfikir kritis tema Panas dan Perpindahannya siswa kelas V SD Negeri Tlogomulyo Semarang".

Berdasarkan latar belakang masalah di atas maka dapat diidentifikasi masalah penelitian antara lain: 1) Peserta didik umumnya kurang aktif berpartisipasi dalam proses pembelajaran, 2) Kemandirian belajar peserta didik masih kurang, 3) Kemampuan berfikir kritis peserta didik masih rendah dalam pembelajaran

Berdasarkan pengetahuan, waktu, dan kemampuan peneliti, maka masalah penelitian dibatasi pada keefektifan model pembelajaran problem based learning terhadap kemampuan berfikir kritis tema Panas dan Perpindahannya siswa kelas V SD Negeri Tlogomulyo.

Berdasarkan latar belakang yang sudah diuraikan, maka rumusan masalah yang dapat diajukan adalah sebagai berikut: Apakah model Problem Based Learning efektif untuk meningkatkan kemampuan berfikir kritis tema Panas dan Perpindahannya siswa kelas V SD Negeri Tlogomulyo?

Tujuan dari penelitian ini adalah untuk mengetahui keefektifan model problem based learning untuk meningkatkan kemampuan berfikir kritis tema Suhu dan Kalor siswa kelas V SD negeri Tlogomulyo.

Kerangka berpikir yang baik akan menjelaskan secara teoritis pertautan antar variabel yang akan diteliti. Jadi secara teoritis perlu dijelaskan hubungan antar variabel independen dan dependen. Bila dalam penelitian ada variabel moderator dan intervening, maka juga perlu dijelaskan, mengapa variabel itu ikut dilibatkan dalam penelitian. Pertautan antar variabel tersebut, selanjutnya dirumuskan kedalam bentuk paradigma penelitian harus didasarkan pada kerangka berpikir (Rusman 2012;91)

Berdasarkan latar belakang masalah, kurangnya kemampuan berfikir kritis siswa dalam pembelajaran tematik yang mengakibatkan siswa pasif dalam kegiatan belajar di dalam kelas dan hasil belajar yang belum maksimal. Dengan menggunakan model problem based learning diharapkan dapat meningkatkan aktivitas siswa, hasil belajar, kemampuan siswa berfikir kritis dalam memecahkan masalah, serta dapat meningkatkan keterampilan guru atau peneliti. Tujuan dari penelitian ini adalah untuk mengetahui keefektifan model pembelajaran problem based learning terhadap kemampuan berfikir kritis tema Panas dan Perpindahannya siswa kelas V SD negeri Tlogomulyo Kabupaten Semarang.

Kerangka berfikir penelitian ini juga dapat disajikan dalam bentuk bagan yang menjelaskan tentang keadaan siswa di sekolah.

Berpikir kritis merupakan pemikiran yang masuk dan reflektif yang berfokus untuk memutuskan apa yang mesti dipercaya atau dilakukan (Ennis dalam Fisher, 2008:4). Keterampilan penting yang harus dikembangkan yang menjadi landasan untuk keterampilan berpikir kritis. Secara sederhana, disajikan tabel indikator berpikir kritis sebagai berikut:

Tabel 1. Indikator Kemampuan Berpikir Kritis Siswa

\begin{tabular}{ll}
\hline \multicolumn{1}{c}{ Keterampilan Berpikir Kritis } & Sub Keterampilan Berpikir Kritis \\
\hline 1. Menjelaskan penjelasan dasar & $\begin{array}{l}\text { 1. Mengenal masalah } \\
\text { 2. Menemukan cara-cara yang dapat } \\
\text { digunakan untuk menangani masalah }\end{array}$ \\
& $\begin{array}{l}\text { 3. Mengumpulkan dan menyusun informasi } \\
\text { yang diperlukan }\end{array}$ \\
2. Membangun keterampilan dasar & $\begin{array}{l}\text { 1. Mengenal asumsi-asumsi yang yang tidak } \\
\text { ditanyaka }\end{array}$ \\
& $\begin{array}{l}\text { 2. Memahami dan menggunakan bahasa } \\
\text { yang tepat, jelas dan khas }\end{array}$ \\
3. Membuat penjelasan lebih lanjut & $\begin{array}{l}\text { 1. Menganalisis data } \\
\text { 2. Menilai fakta dan mengevaluasi pertanya }\end{array}$ \\
& 3. Mengenal adanya hubungan yang logis \\
antara masalah-masalah
\end{tabular}


TSCJ, Vol 2 No 1, Tahun 2019

p-ISSN : 2615-4692 e-ISSN : 2615-6105

4. Membuat strategi dan teknik

5. Membuat kesimpulan
1. Menyusun kembali pola-pola keyakinan seseorang berdasarkan pengalaman yang lebih luas

2. Membuat penilaian yang tepat tentang halhal dan kualitas-kualitas tertentu dalam kehidupan sehari-hari

1. Menarik kesimpulan-kesimpulan dan halhal dan kualitas-kualitas tertentu dalam kehidupan sehari-hari

2. Menguji kesamaan dan kesimpulankesimpulan yang seseorang ambil

Metode yang digunakan dalam penelitian ini adalah metode penelitian eksperimen. Metode penelitian eksperimen merupakan metode penelitan yang digunakan untuk mencari pengaruh treatment (perlakuan) tertentu (Sugiyono, 2016; 11-12).

Arikunto (2014: 9) menjelaskan bahwa "eksperimen adalah suatu cara untuk mencari hubungan sebab akibat (hubungan kausal) antara dua faktor yang ditimbulkan oleh peneliti dengan mengeliminasi atau mengurangi atau menyisihkan faktor-faktor lain yang mengganggu". Penelitian yang dilakukan oleh peneliti adalah dengan pre eksperimental design.

Penelitian ini menggunakan metode eksperimen dengan one group pretest posttest design dengan tujuan untuk melihat akibat dari suatu perlakuan. Kelas yang digunakan dalam penelitian ini satu. Alur dari penelitian eksperimen ini adalah dengan memberikan pretest untuk mengukur kemampuan awal peserta didik. Kemudian peserta didik diberi perlakuan dari peneliti. Terakhir peserta didik mengerjakan posttest untuk mengetahui kemampuan peserta didik setelah diberi perlakuan.

Pada penelitian eksperimen ini peneliti melakukan perlakuan dengan melakukan pembelajaran menggunakan metode eksperimen. Akibat dari perlakuan tersebut adalah peningkatan keterampilan proses tema panas dan perpindahannya subtema suhu dan kalor.

\section{Metode}

Penelitian ini menggunakan metode eksperimen dengan one group pretest posttest design dengan tujuan untuk melihat akibat dari suatu perlakuan. Kelas yang digunakan dalam penelitian ini satu. Alur dari penelitian eksperimen ini adalah dengan memberikan pretest untuk mengukur kemampuan awal peserta didik. Kemudian peserta didik diberi perlakuan dari peneliti. Terakhir peserta didik mengerjakan posttest untuk mengetahui kemampuan peserta didik setelah diberi perlakuan. Pada penelitian eksperimen ini peneliti melakukan perlakuan dengan melakukan pembelajaran menggunakan metode eksperimen. Akibat dari perlakuan tersebut adalah peningkatan keterampilan proses tema panas dan perpindahannya subtema suhu dan kalor. Desain pada penelitian eksperimen ini peneliti menggunakan Pre Experimental Design dengan bentuk One Group Pretest Posttest Design.

$$
\mathrm{O}_{1} \times \mathrm{O}_{2}
$$

Gambar 1 Desain Penelitian

Tabel 2. Keterangan Bentuk Desain penelitian:

\begin{tabular}{cl}
\hline $\mathrm{O}_{1}:$ & $\begin{array}{l}\text { Nilai tes awal (sebelum menggunakan model pembelajaran } \\
\text { problem based learning) } \\
\text { Nilai tes akhir (setelah menggunakan model pembelajaran problem } \\
\text { based learning) }\end{array}$ \\
$\mathrm{O}_{2}:$ & Penggunaan model problem based learning. \\
$\mathrm{X}:$ &
\end{tabular}

Sugiyono (2016: 117) Populasi adalah wilayah generalisasi yang terdiri atas obyek/subjek yang mempunyai kualitas dan karakteristik tertentu yang ditetapkan oleh peneliti 
untuk dipelajari dan kemudian ditarik kesimpulannya. Dalam penelitian ini yang menjadi populasi adalah siswa Kelas V SD Negeri Tlogomulyo yang masih tercatat aktif sebagai siswa di sekolah selama penelitian ini dilakukan.

Sampel penelitian ini yaitu peserta didik kelas V SD Negeri Tlogomulyo yang mana jumlah peserta didik kelas $V$ adalah 45 siswa.

Penelitian eksperimen yang peneliti lakukan menggunakan teknik pengumpulan data sebagai berikut: (1) wawancara (2) tes (3) dokumentasi.

Menurut Sugiyono,(2016;305) Dalam penelitian kuantitatif, kualitas instrumen penelitian berkenaan dengan validitas dan reliabilitas instrumen dan kualitas pengumpulan data berkenaan ketepatan cara-cara yang digunakan untuk mengumpulkan data. Dalam penelitian ini dilakukan uji coba penelitian yang berbentuk tes dan selanjutnya diukur validitas, reliabilitas, taraf kesukaran serta daya pembeda.

untuk mengetahui keefektifan metode pembelajaran dengan membandingkan data pada pretest dan posttest penggunaaan metode eksperimen. Rumus yang digunakan untuk analisis eksperimen menggunakan pretest dan posttest one group design maka menggunakan uji $\mathrm{t}$ adalah :

$$
\mathrm{t}=\frac{M d}{\sqrt{\frac{\sum x^{2}}{N(N-1)}}}
$$

Keterangan :

$$
\begin{aligned}
& M d \text { : mean dari perbedaan pretest dengan posttest } \\
& X d \quad \text { : deviasi masing-masing subjek }(\mathrm{d}-\mathrm{Md}) \\
& \sum_{N} x^{2} d: \text { jumlah kuadrat deviasi } \\
& \mathrm{db} \quad \text { : banyaknya sampel } \\
& \mathrm{d} . \text { ditentukan dengan } \mathrm{N}-1
\end{aligned}
$$

(Arikunto, 2014: 349)

\section{Hasil dan Pembahasan}

Penelitian ini dilaksanakan di SD N Tlogomulyo Kabupaten Semarang dengan memilih kelas $\mathrm{V}$ sebagai sampel penelitian. Jumlah sampel dalam penelitian ini adalah 45 peserta didik yang terdiri dari 24 peserta didik perempuan dan 20 peserta didik laki-laki. Desain eksperimen pada penelitian ini dengan jenis one group pretest posttest design. Dalam design ini terdapat pretest sebelum diberi perlakuan untuk mengetahui keadaan awal dan posttest untuk mengetahui hasil belajar setelah diberi perlakuan. Penelitian ini merupakan penelitian untuk mengetahui keefektifan model problem based learning terhadap kemampuan berpikir kritis tema Panas dan Perpindahannya siswa kelas V SD N Tlogomulyo Semarang. Data penelitian diperoleh dari hasil belajar siswa sebelum dan sesudah menggunakan model problem based learning.

Dari nilai pretest sebagai nilai awal diperoleh memberikan soal uraian yang berjumlah 15 soal dan data nilai posttest sebagai nilai akhir diperoleh dengan memberikan soal evaluasi berupa uraian dengan 15 butir soal. Data kemampuan berpikir kritis pretest dan posttest diketahui rata-rata hasil pretest adalah 48 sedangkan rata-rata hasil posttest adalah 79 . Berikut adalah data dari nilai pretest dan posttest kemampuan berpikir kritis siswa SD Negeri Tlogomulyo.

Tabel 3 Hail Pretest dan Posttest

\begin{tabular}{ccc}
\hline Sumber variasi & Pretest & Posttest \\
\hline Nilai Tertinggi & 68 & 98 \\
Nilai Terendah & 27 & 58 \\
Rata-rata & $\mathbf{4 8}$ & $\mathbf{8 3}$ \\
\hline
\end{tabular}

Berdasarkan Tabel 3 di atas dapat dilihat bahwa selisih nilai pretest tertinggi dan terendah berbeda. Nilai tertinggi 68 , sedangkan nilai terendahnya adalah 27 . Nilai rata-rata 
kelas 48 dan belum ada siswa yang mendapatkan nilai tuntas. Hal tersebut menunjukkan Kriteria Ketuntasan Minimum (KKM) yaitu sama dengan 70. berikut :

Dari data pretest dan posttest tersebut dapat digambarkan dalam diagram sebagai

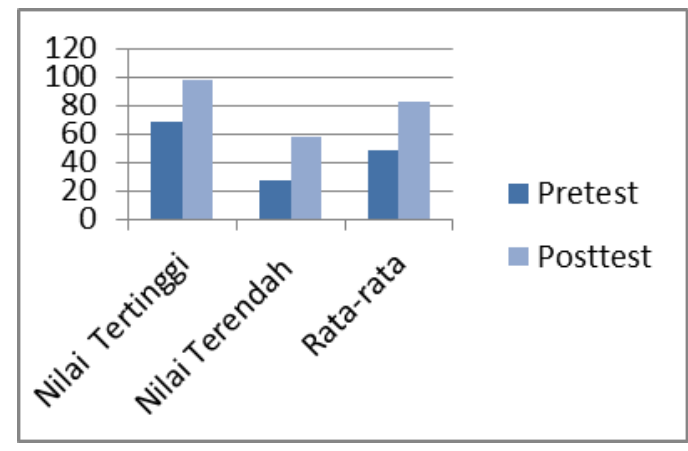

Gambar 2 Diagram Pretest dan Posttest

Tabel 4. Kategori Nilai Pretest dan Posttest Kemampuan Berpikir Kritis Siswa

\begin{tabular}{cllcccc}
\hline \multirow{2}{*}{ No. } & \multirow{2}{*}{ Skala Perolehan } & & \multirow{2}{*}{ Kategori } & \multicolumn{2}{c}{ Jumlah siswa } & \multicolumn{2}{c}{ Presentase } \\
\cline { 3 - 6 } & & Pre & Post & Pre & Post \\
\hline 1. & $81,25-100$ & Sangat Kritis & 0 & 26 & $0 \%$ & $58 \%$ \\
2. & $62,50-81,25$ & Kritis & 5 & 15 & $11 \%$ & $33 \%$ \\
3. & $43,75-62,50$ & Kurang Kritis & 26 & 4 & $58 \%$ & $9 \%$ \\
4. & $25,00-43-75$ & Sangat Kurang Kritis & 11 & 0 & $24 \%$ & $0 \%$ \\
\hline
\end{tabular}

Berdasarkan Tabel 4, dapat dilihat bahwa tes kemampuan berpikir kritis siswa sebelum perlakuan belum terdapat siswa dengan kategori sangat kritis, 5 siswa dengan kategori kritis, 26 siswa dengan kategori kurang kritis, dan 11 siswa dengan kategori sangat kurang kritis. Data hasil tes siswa setelah menggunakan model Problem Based Learning menunjukkan bahwa 26 siswa dengan kategori sangat kritis, 15 siswa dengan kategori kritis, 4 siswa dengan kategori kurang kritis dan 0 siswa dengan kategori sangat kurang kritis. Berdasarkan batas ketuntasan yang telah ditentukan pada konversi nilai 62,50 yaitu pada kategori kritis, maka presentase ketuntasan berpikir kritis siswa dapat ditunjukkan dalam gambar.

Pada pertemuan pertama, siswa diberikan perlakuan dengan menggunakan model pembelajaran problem based learning. Hal ini bertujuan supaya siswa dapat menyelesaikan masalah dengan baik. Dimulai pemahaman mendalam untuk menyelesaikan permasalahan yang ada. Pada pertemuan kedua, siswa diminta untuk menyelesaikan masalah yang telah disajikan oleh guru sehingga dapat menggali kemampuan berfikir kritis siswa. Kemudian guru memberikan soal kemampuan berpikir kritis. Berdasarkan dari hasil statistik, diperoleh kesimpulan bahwa hipotesis $\mathrm{H}_{O}$ dan $\mathrm{H}_{a}$ diterima. Berdasarkan hipotesis, keefektifan model pembelajaran problem based learning dibandingkan dengan pembelajaran metode konvensional kemampuan berpikir kritis siswa tema panas dan perpindahannya siswa kelas $\mathrm{V}$ lebih baik dari sebelumnya. Hasil anailisis akhir yang telah dilakukan dengan uji normalitas menunjukkan bahwa sampel tersebut berasal dari populasi yang berdistribusi normal. Berdasarkan perhitungan nilai pretest yang dilakukan diperoleh kesimpulan bahwa kelas V SD Tlogomulyo berdistribusi normal karena nilai $\mathrm{L}_{o}<\mathrm{L}_{\text {tabel }}$ yaitu $0,016<0,132$ dengan $\mathrm{n}=45$ dan taraf nyata a $=0,05$. Pada tahap akhir berikutnya dilakukan uji normalitas dengan menggunakan nilai posttest. Berdasarkan perhitungan diperoleh $\mathrm{L}_{O}=0,089$ dengan $\mathrm{n}=45$ dan taraf nyata $\mathrm{a}=0,05$, dari daftar nilai kritis $L$ di dapat $\mathrm{L}_{\text {tabel }}=0,132$, karena $\mathrm{L}_{0}<\mathrm{L}_{\text {tabel }}$ yaitu $0,089<0,132$, maka $\mathrm{H}_{o}$ diterima sehingga dapat disimpulkan bahwa sampel berasal dari populasi berdistribusi normal.

Setelah dilakukan pengujian hipotesis dengan analisis kemampuan berpikir kritis siswa pada tema panas dan perpindahnnya ranah kognitif diperoleh nilai rata-rata kelas untuk pretest 
sebesar 48 dan posttest sebesar 83 dengan $n=45$ jadi $d b=N-1$ yang diperoleh $t_{\text {hitung }}=23,865$ $>\mathrm{t}_{\text {tabel }}=1,671$. Karena $\mathrm{t}_{\text {hitung }}>\mathrm{t}_{\text {tabel }}$ yaitu 23,865 $>1,671$ maka $\mathrm{H}_{\circ}$ ditolak dan $\mathrm{H}_{a}$ diterima. Sehingga dapat dilakukan uji sample one $t$-test untuk mengetahui ketuntasan kemampuan berpikir kritis siswa tema panas dan perpindahannya, dengan hasil analisis data diperoleh hasil analisis data $t_{\text {hitung }}$ sebesar 23,865 dengan taraf signifikan 5\% didapat nilai

$\mathrm{t}_{\text {tabel }} 1,671$ maka $\mathrm{H}_{o}$ ditolak dan $\mathrm{H}_{a}$ diterima sehingga hasil kemampuan berpikir kritis siswa kelas V SD Negeri Tlogomulyo tuntas. Dan demikian tujuan penelitian telah tercapai yaitu peneliti telah membuktikan bahwa model pembelajaran problem based learning efektif terhadap kemampuan berpikir kritis tema panas dan perpindahannya siswa kelas V SD Negeri Tlogomulyo Semarang.

\section{Simpulan dan Saran}

Berdasarkan pembahasan hasil penelitian yang didasarkan pada analisis data statistik dan kenyataannya dilapangan sehingga peneliti dapat menyimpulkan bahwa dengan model problem based learning dapat meningkatkan kemampuan berpikir kritis siswa pada pembelajaran tema 6 subtema 1 pembelajaran 1, 2 dan 5 kelas $V$ SD Negeri Tlogomulyo Semarang. Hal ini dibuktikan dengan hipotesis menggunakan uji t diperoleh hasil $\mathrm{db}=\mathrm{N}-1=45$ $1=44$ dan taraf signifikan 0,05 sebesar 1,671. Karena $t_{\text {hitung }}>t_{\text {tabel }}$ yaitu 23,865 $>1,671$ maka $\mathrm{H}_{0}$ ditolak dan $\mathrm{H}_{a}$ diterima. Sehingga dapat dikatakan bahwa model pembelajaran problem based learning efektif terhadap kemampuan berpikir kritis siswa kelas V SD Negeri Tlogomulyo Semarang.

Berdasarkan hasil penelitian pada siswa kelas V SD Negeri Tlogomulyo pada semester 2 tahun pelajaran 2018/2019, maka penulis perlu menyampaikan saran sebagai berikut: 1) Disarankan agar model pembelajaran problem based learning dapat dijadikan salah satu model pembelajaran alternatif meningkatkan keaktifan siswa aga siswa tidak bosan dengan pembelajaran yang hanya menggunakan pembelajaran konvensioal. 2) Pada penelitian ini peneliti belum menggunakan media pembelajaran, disarankan pada penelitian selanjutnya tentang model pembelajaran problem based leraning dibantu dengan sebuah media pembelajaran agar pembelajaran berjalan semakin menarik.

\section{DaftarPustaka}

Afrizon, renal. dkk. 2012. Peningkatan Perilaku Berkarakter Dan Keterampilan Berfikir Kritis Siswa Kelas IX MtsN Padang Pada Mata Pelajaran IPA-Fisika Menggunakan Model Problem Based Instruction. Jurnal penelitian pembelajaran fisika 1 (2012) 1-16. ISSN: 2252-2014 Februari 2012 http://ejournal.upp.ac.id.

Arikunto. 2012. Dasar-dasar Evaluasi Pendidikan. Jakarta : Bumi Aksara.

Arikunto, Suharsimi. 2013 Prosedur Penelitian (Suatu Pendekatan Praktik). Jakarta : Rineka Cipta.

Arifin, Zainal. 2009. Evaluasi Pembelajaran. Bandung: Remaja Rosdakarya.

Azmi, Muhamad Khairul, Satutik Rahayu, Hikmawati. 2016. Pengaruh Model Problem Based Learning dengan Metode Eksperimen dan Diskusi Terhadap Hasil Belajar Fisika Ditinjau dari Sikap Ilmiah Siswa Kelas X MIPA SMA N 1 Mataram. Jurnal Pendidikan Fisika dan Teknologi Volume II No 2 Hal. 86-94. Tersedia Pada : http://download.garuda.ristekdikti.go.id/article.php?article=917835\&val=14364\&title=Pen garuh\%20Model\%20Problem\%20Based\%20Learning\%20dengan\%20Metode\%20Ekspe rimen\%20dan\%20Diskusi\%20Terhadap\%20Hasil\%20Belajar\%20Fisika\%20Ditinjau\%20 dari\%20Sikap\%20llmiah\%20Siswa\%20Kelas\%20X\%20MIPA\%20\%20SMA\%20N\%201 $\% 20$ Mataram.

Dewina, Sindy, Ondi Suganda, Rahma Widiantie. 2017. Pengaruh Model Pembelajaran Problem Based Learning (PBL) terhadap Kemampuan Menganalisis dan Keterampilan 
Berargumentasi Siswa pada Konsep Pencemaran Lingkungan di Kelas X. Jurnal Pendidikan dan Biologi Volume 9, Nomor 2 Hal. 46-54. Tersedia Pada : https://journal.uniku.ac.id/index.php/quagga/article/view/748.

Fauziah, Intan, Samsul Maarif, Trisna Roy Pradipta. 2018. Peningkatan Kemampuan Komunikasi Matematis dan Self Regulated Learning Siswa Melalui Model Problem Based Learning (PBL). Jurnal Analisa Vol. 4 No. 2 Hal. 90-98. Tersedia Pada : http://journal.uinsgd.ac.id/index.php/analisa/index.

Hamdayana. 2016. Metodologi Pengajaran. Jakarta : Bumi Aksara.

Hosnan. 2014. Pendekatan Saintifik \& Kontekstual Dalam Pembelajaran Abad 21: Kunci Sukses Implementasi Kurikulum 2013. Bogor : Ghalia Indonesia.

Kasturi, dkk. 2015. Pengembangan Perangkat Pembelajaran Problem Posing Berorientasi Penerapan Hots Pada Materi Kesebangunan Kelas IX. Jurnal Pancaran, Vol. 4, No. 1, hal 11-32, Februari 2015.

Kurniawan, Deni. 2014. Pembelajaran Terpadu Tematik (Teori, Praktik, dan Penilaian). Bandung : Alfabeta.

Lutvaidah, Ukti.2015. Pengaruh Metode dan Pendekatan Pembelajaran terhadap Penguasaan Konsep Matematika. Jurnal Formatif Vol. 5 No. 3 Hal. 279-285. Tersedia Pada : https://journal.Ippmunindra.ac.id/index.php/Formatif/article/view/653.

Rusman. 2014. Model-model Pembelajaran. Mengembangkan profedionaliseme guru.Jakarta : Rajawali.

Rusman .2015. Pembelajaran Tematik Terpadu. Teori praktik dan penilaian. Jakarta : Raja wali.

Rusman. 2017. Belajar dan Pembelajaran (Berorientasi Standar Proses Pendidikan). Jakarta : Rajawali.

Sianturi, Aprilita, Tetty Natalia Sipayung, dan Frida Marta Argareta Simorangkir. 2018. Pengaruh Model Problem Based Learning (PBL) terhadap Kemampuan Berpikir Kritis Matematis Siswa SMPN 5 Sumbul. UNION: Jurnal Pendidikan Matematika Vol 6 No 1 Hal. 29-42. Tersedia Pada : http://jurnal.ustjogja.ac.id/index.php/union/article/view/2082.

Sudjana. 2015. Metoda Statistika. Bandung : Tarsito.

Sugiyono. 2012. Statistika untuk Penelitian. Bandung : Alfabeta.

Sugiyono. 2016. Metodelogi Penelitian Pendidikan. Bandung: Alfabeta.

Sugiyono.2017. Metodelogi Penelitian Pendidikan. Bandung : Alfabeta.

Undang-Undang Republik Indonesia. 2003. Undang-Undang Nomor 20 Tahun 2003 Tentang Sistem Pendidikan Nasional. Jakarta: Dikbud. 